\title{
Extending the frontiers of employment regulation: The case of domestic employment in South Africa
}

\author{
DARCY DU TOIT \\ Professor of Law, University of the Western Cape
}

\begin{abstract}
"What do we do as workers? We have highlighted those things, the failure of the Department of Labour, the failure of our employers to see us human beings... you know they treat us without dignity but, as workers, what do we do for ourselves do we sit back? There are laws in South Africa and they say you have a right to join a trade union. [Minister of Labour] Mdladlana speaks of unionism. What do we do to fight these conditions that are appalling?"1
\end{abstract}

\section{INTRODUCTION}

Over recent decades the precarious nature of domestic employment has been analysed in depth from sociological, historical, economic and legal perspectives, both in South Africa and internationally. In the process certain key conclusions have become widely accepted and have served as points of departure for ongoing research. A milestone in South Africa was the analysis by Jacklyn Cock published in $1980,{ }^{2}$ hailed almost 30 years later as a "classic study of power relations between maids and their employers in the Eastern Cape of apartheid South Africa". ${ }^{3}$

Describing the different worlds inhabited by white women and their black female servants, the book developed a paradigm of the domestic employment relationship which to a large extent remains valid today: a relationship which is liberating for the (white) employer but exploitative of the (black) employee, even though both are women experiencing the general oppression of women, but in vastly different ways.

\footnotetext{
${ }^{1}$ Statement by participant at focus group discussion organised by Domestic Workers Research Project, Cape Town, 28 February 2009.

${ }^{2}$ Maids \& Madams: A Study in the Politics of Exploitation (Ravan Press 1980), republished as Maids and Madams: Domestic Workers under Apartheid (The Women's Press, 1989). For discussion of the feminist aspect of the study, see review of the 1989 edition by Deborah Gaitskell in Southern African Review of Books, Issue 11, October/November 1989.

${ }^{3}$ Francis B Nyamnjoh Insiders and Outsiders: Citizenship and Xenophobia in Contemporary Southern Africa ( Zed Books, 2006). For discussion of the feminist emphasis of the 1989 edition, see review by Deborah Gaitskell in Southern African Review of Books, Issue 11, October/November 1989.
} 
What starkly characterised it was the interconnection of class, gender and racial subjugation. Although the racial dimension has become less pronounced since the demise of apartheid, with growing numbers of black employers of domestic workers joining their white counterparts, the multi-layered nature of the inequality embodied by the relationship has continued. ${ }^{4}$ The vast majority of domestic workers are poorly-paid African or coloured women, singled out for this role, as it were, by the coincidence of their class, race and gender. In this sense domestic employment remains an institution with roots deeply embedded in colonial society, regardless of the identity of the employer. Seeking to abolish its oppressive characteristics means addressing not only patterns of behaviour that have become established over centuries but also the (self)perceptions that have been generated and have become equally deeply-rooted.

This article will not try to cover ground that has already been covered, nor seek to address all the issues bound up with domestic work. As explained below, its purpose is more specific: in the context of current debate about setting international standards for the domestic employment sector, it examines what has been achieved in South Africa over the past decade in extending legal protection to domestic workers, problems that have been encountered and possible ways in which those problems may be addressed. The question is not a simple one. On the one hand, law is obviously important: not only does it set parameters for permissible conduct, it embodies values by which those parameters are justified and which society is expected to embrace. South Africa is fortunate in having a Constitution ${ }^{5}$ clearly stating the value system on which the post-apartheid dispensation was and is to be built. The fundamental rights contained in the Constitution - in particular the rights to dignity, equality and fair labour practices form self-evident starting points in understanding what any given law sets out to achieve and how it should be interpreted.

At the same time, the law can only do so much. The quotation above speaks of the frustration of domestic workers at ongoing exploitation and inequality. More than legislation will be needed in changing the complex of political, social and economic factors by which that inequality is maintained. To do this will mean unravelling the heritage of centuries of degradation, inequality and exploitation in very concrete forms. In guiding this process the law must engage with members of society those who dominate as well as the subjugated - as it finds them and define a route towards realisation of the constitutional vision which they are able to follow. Nowhere is this interaction more complex and challenging than in the domestic employment sector, where the new dispensation has hardly begun to take root. It is in this context that the issues addressed in the article need to be understood.

\footnotetext{
${ }^{4}$ See, for example, Xoliswa Dilata and Kholofelo Ruth Ngoepe "The study of African domestic workers and their African employers in the townships of Soweto": paper to be presented at conference "Exploited, Undervalued - and Essential", Cape Town, 7-8 May 2010; abstract available at http://dwrp.org.za/images/stories/DWRP Research/abstract dilata.pdf.

${ }^{5}$ Constitution of the Republic of South Africa, 1996 (hereafter "the Constitution").
} 


\section{DOMESTIC WORK IN PERSPECTIVE}

Domestic employment is an international phenomenon, as are many of the issues it raises. It is extremely widespread. The term generally refers to work performed in and for private households, and "domestic workers" refers to persons employed for this purpose. ${ }^{6}$ Although there are no comprehensive statistics, the number of domestic workers internationally is estimated at over 100 million and probably increasing. ${ }^{7}$

Apart from its size, the domestic sector is characterised by a number of socially significant features. First, most workers are women; the sector is thus an important source of female employment worldwide. Secondly, domestic workers are largely unorganised. ${ }^{8}$ Thirdly, domestic employment is to a large extent "informal". Although this term is elastic and difficult to define, ${ }^{9}$ it is used here to denote work that is done outside the framework of legal regulation, either because it is technically exempt from regulation or (more commonly) because employers do not comply with the applicable legislation. To the extent that conditions in the domestic sector mirror those that are found elsewhere in the informal economy, it may also be seen as a case study of the scope for extending legal regulation to other parts of the informal economy.

Finally and most importantly for present purposes, conditions of employment in the domestic sector are generally poor and often very poor, in the worst cases amounting to servitude rather than employment. Domestic work, the ILO Report explains, tends to be

"undervalued and poorly regulated, and many domestic workers remain overworked, underpaid and unprotected. 'Accounts of maltreatment and abuse,

\footnotetext{
${ }^{6}$ International Labour Office Decent work for domestic workers Report IV(1), International Labour Conference, 99th Session, 2010: Geneva, First edition 2010 (hereafter "the ILO Report") at http://www.ilo.org/wcmsp5/groups/public/---ed_norm/--relconf/documents/meetingdocument/wcms 104700.pdf (accessed 20 June 2009), pars 100-102. ${ }^{7}$ International Trade Union Confederation "Spotlight interview with Barbro Budin (IUF - Equality Officer)" at http://www.ituc-csi.org/spip.php?article1895 (19 June 2009. See also ILO Report at par 20.

${ }^{8}$ The two registered trade unions of domestic workers in South Africa, the South African Domestic Services and Allied Workers Union (SADSAWU) and the South African Domestic and General Workers Union (SADAGWU) between them organise no more than an estimated 5\% of all domestic workers.

${ }^{9} \mathrm{Cf}$ International Labour Organisation Women and Men in the Informal Economy: A Statistical Picture (2002) at http://www.wiego.org/publications/women\%20and\%20men\%20in\%20the\%20informal \%20economy.pdf (accessed 19 June 2009) at 11-13.
} 
especially of live-in and migrant domestic workers, are regularly denounced in the media." 10

This state of affairs is hardly accidental; it may be seen as a product of the interconnected forms of inequality discussed in the Introduction. The fact that the workers are mainly women exposes them to discrimination based on sex and/or gender, aggravated by lack of organisation and de facto absence of legal protection. The domestic employment relationship plays itself out in private households, beyond the reach of trade unions or law enforcement agencies, involving relatively powerful employers and relatively powerless (female) workers who seldom have the option of alternative employment. Terms of employment are typically imposed by the employer. The resultant working conditions are often deeply subversive of the dignity and human potential not only of domestic workers themselves but also, directly or indirectly, of their family members and dependants.

Concern has grown in recent decades at the disempowerment, exploitation and abuse experienced by so many women in the domestic sector. ${ }^{11}$ In 2008 the International Labour Organisation (ILO) took a milestone decision to place the issue of domestic employment on the agenda of the 2010 International Labour Conference with a view to adopting a Convention on decent work for domestic workers. "Decent work" has been explained as being

"a strategic goal for development that acknowledges the central role of work in people's lives. This includes work that is productive and delivers a fair income; provides security in the workplace and social protection for families; and offers better prospects for personal development and social integration, freedom to express concerns, opportunities to organize and participate in decision-making, and equal opportunity and treatment for all women and men." 12

Very importantly, it is understood that the achievement of this goal will involve not only legislative change but also practical interventions - above all, measures to promote the empowerment and mobilisation of domestic workers themselves. A considerable amount of work towards these ends has already been done. Amongst other things an international network of domestic workers' trade unions and support organisations has been established, ${ }^{13}$ and a detailed report prepared for

\footnotetext{
${ }^{10}$ ILO Report par 3. Cf Thenjiwe Magwaza "Effects of Domestic Workers Act in South Africa: A steep road to recognition" Agenda No 78 (2008).

11 Organised labour has played a prominent part in highlighting these conditions and seeking ways of addressing them; see, for example, statement by the International Trade Union Confederation dated 13 February 2008 at http://www.ituc-csi.org/spip.php?article1811 (accessed 20 June 2009) and "Spotlight interview with Esther Stevens (SADSAWU - South Africa)" at http://www.ituccsi.org/spip.php?article1483\&lang=en (accessed 20 June 2009).

12 ILO "Tackling the 'decent work deficit'" at http://www.ilo.org/global/About the ILO/Media and public information/Feature stories/lang--en/WCMS 071242/index.htm (accessed 10 June 2009).

${ }^{13}$ International Domestic Workers Network "Respect and Rights for Domestic Workers" at http://www.domesticworkerrights.org/ (accessed 20 June 2009). The aims of the network are "to assist in the organisation of domestic workers' unions where they do not yet exist; to serve as a clearing house for the exchange of information; to organise mutual support and solidarity; to
} 
the forthcoming International Labour Conference gives a summary of the extensive research that has been carried out. ${ }^{14}$

This article is intended as a contribution to the discussion that has been generated by these developments. It draws on information contained in the ILO Report as well as on the first phase of a research project dealing with the regulation of domestic employment in South Africa. ${ }^{15}$ While recognising that regulation and implementation go hand in hand, it is assumed that an appropriate regulatory framework is a necessary basis for effective intervention. Specifically, the focus is on the manner in which labour market regulation in South Africa has been extended to take account of the realities of the domestic employment sector and might be extended further in the light of international best practice. The outcomes of the existing regulation will be considered as indicators of its effectiveness or, where the desired results are not achieved, of the need for further development. In conclusion, suggestions are made of possible lines that such development might take in the domestic employment sector and, to the extent that they are applicable, in other parts of the informal economy.

\section{THE REGULATION OF DOMESTIC WORK: A CONCEPTUAL FRAMEWORK}

The ILO Report follows a rights-based approach to the regulation of domestic work; that is, the purpose of legislation is regarded as the implementation of certain basic rights that are subsumed under the rubric of "decent work". ${ }^{16}$ In contrast to the contractual paradigm in terms of which lawyers have traditionally explained the employment relationship, this paper follows a similar approach. It does so for the reasons captured in Kahn-Freund's famous statement that "the relation between an employer and an isolated employee or worker is typically a relation between a bearer of power and one who is not a bearer of power". ${ }^{17}$ The argument continues:

"In its inception it [the employment relationship] is an act of submission, in its operation it is a condition of subordination, however much the submission and the

advance common political aims (international standards, national legislation); to represent domestic workers at international level; and to secure the support of the wider labour movement for each of these objectives": ibid.

14 See fn 6 above.

15 The Domestic Workers' Research Project, funded by FNV Mondiaal in the Netherlands and working in cooperation with local domestic workers' unions, was launched in January 2009 at the University of the Western Cape. It is aimed inter alia at influencing domestic legislative reform and promoting organisation and empowerment of domestic workers as well as contributing to the proposed ILO Convention.

16 See Chapter II, ILO Report.

17 Davies and Freedland Kahn-Freund's Labour and the Law $3^{\text {rd }}$ ed Stevens (1983) at p18. 
subordination may be concealed by that indispensable figment of the legal mind known as the 'contract of employment'." 18

A contract, in other words, presupposes agreement between equals - that is, between parties equally able to stipulate the terms that they find acceptable and walk away if the other party does not agree. Workers in general cannot do so; the labour market is a buyer's market far more often than a seller's market. From this premise Kahn-Freund went on to draw two further conclusions. First, given their individual weakness in the market-place, workers need to act collectively in order to develop the bargaining power they need to negotiate the terms on which they are employed. The "principal purpose of labour law", from this standpoint, "is to regulate, to support and to restrain the power of management and the power of organised labour" - which, in practice, comes down to "ensuring the effective operation of a voluntary system of collective bargaining". 19

Law thus plays a secondary role in relation to the primary means by which employment relations are determined: that is, the exercise of power by the protagonists. This is not to say that law does not serve other purposes. It can, and does, lay down basic protections (such as maximum hours of work) for the benefit of unorganised or poorly-organised workers who lack the means to negotiate their own terms of employment. But, given what has just been said, this is problematic. If individual workers lack the power to compel employers to negotiate with them, they may also lack the power to compel reluctant employers (on whom they depend for their living) to observe the protections laid down by law. Kahn-Freund expressed this as follows:

"Where labour is weak - and its strength or weakness depends largely on factors outside the control of the law - Acts of Parliament, however well intentioned and well designed, can do something, but cannot do much to modify the power relation between labour and management." 20

Even in the area of securing compliance with the law, in other words, worker organisation is essential - or, as Kahn-Freund put it, "[e]verywhere the effectiveness of the law depends on the unions far more than the unions depend on the effectiveness of the law." 21

It is trite that the world has changed a great deal since the heyday of Fordism when these ideas were formulated. The processes referred to as globalisation have tilted the scales more heavily in favour of (transnational) employers while, at the same time, the power of organised labour has been eroded. The role of the law is more limited than ever in seeking to regulate the operation of market forces playing themselves out in transnational settings, beyond the reach of governments to

\footnotetext{
18 Ibid. See also Rycroft \& Jordaan A Guide to South African Labour Law 2 ed (Juta 1992) Chapter 1.

19 Ibid at 15 and 2.

20 Ibid 19.

21 Ibid 21.
} 
control. Organised labour, and labour analysts, have been forced to engage with a broader range of factors, over and above collective bargaining, to come to grips with the ways in which labour markets are regulated on a global scale. ${ }^{22}$ By the same token, trade unions have come to rely on broader alliances - for example, with civil society organisations - in order to exert pressure on multinational employers. The basic inequality between workers and employers, therefore, remains as stark as ever. What has changed, mainly, is that trade unions are increasingly finding it necessary to go beyond the traditional forms of trade unionism in seeking to combat the consequences of this inequality.

It is against this unpromising background that a rights-based approach to the position of domestic workers is proposed. At first glance the notion of fundamental rights, even when applied horizontally, ${ }^{23}$ might seem as idealistic in this context as the notion of agreement between equals. Unlike the individualistic principles of contract, however, a rights-based approach presupposes a more holistic vision. The function of law, from this standpoint, is not merely to promote bargaining parity between employers and employees but, rather, to give effect to the fundamental rights of workers within the employment relationship.

Fundamental rights, moreover, are applied not only by means of law; it is equally incumbent on the executive branch of government to develop the necessary policies within the existing legal framework to implement those rights and manage its administrative agencies accordingly. In the domestic sector, as in other sectors, all the factors by which the labour market is regulated - to the extent that government has control over them - may be expected to be coordinated in such a way as to advance the realisation of the relevant constitutional rights.

The ILO Report identifies the basic rights to freedom of association, equality and non-discrimination, as well as the prohibition of forced labour and child labour, as being central to the achievement of decent work in the domestic sector. ${ }^{24}$ These

\footnotetext{
${ }^{22}$ For example, education and training, equality legislation and policy development; for discussion from a South African perspective, see Paul Benjamin Labour Market Regulation: International and South African Perspectives (Employment \& Economic Policy Research Programme, Human Sciences Research Council, October 2005); Paul Benjamin “Beyond 'lean' social democracy: labour law and the challenge of social protection" (2006) 60 Transformation 32.

23 "Vertical" application of rights refers to their application as between the state and persons whereas "horizontal" application refers to the application of rights as between persons. In terms of section 8(2) of the Constitution, "[a] provision of the Bill of Rights binds a natural or a juristic person [i.e., horizontally] if, and to the extent that, it is applicable, taking into account the nature of the right and the nature of any duty imposed by the right". Employment rights are examples par excellence of fundamental rights with horizontal application: see, e.g., Brassey and Cooper "Labour Relations" in Chaskalson et al Constitutional Law of South Africa (Juta 1996) at 30-13.

24 See ILO Report pars 60-82. The right to equality suggests an intersection between the traditional starting point of labour law (that is, the inequality between employer and employee) and a rightsbased approach. Labour law, however, is concerned primarily with inequality of bargaining power, whereas the constitutional concept is concerned with all forms of inequality to the extent that they
} 
rights are equally central to South African employment and labour legislation. Freedom of association is guaranteed by sections 18 and 23(2) to (5) of the Constitution and regulated by Chapters II and III of the Labour Relations Act ("the LRA"). ${ }^{25}$ The right to equality and non-discrimination is guaranteed by section 9 of the Constitution and regulated by the Employment Equity Act ("the EEA"). ${ }^{26}$ Forced labour and child labour are prohibited by sections 13, 22 and 28 of the Constitution and implemented by Chapter Six of the Basic Conditions of Employment Act ("the BCEA"). ${ }^{27}$

Closely related to the right to equality is the right to dignity (section 10, Constitution). Though impossible to embody in a single statute, it is submitted that realisation of this right - which forms one of the foundational values of the Constitution as a whole - underpins all the objectives of employment legislation. The abuses which the law seeks to prevent amount, at the same time, to violations of employees' dignity; similarly, all the outcomes which the law envisages amount to the assertion of their dignity. Upholding the dignity of traditionally subjugated workers such as domestic workers vis-à-vis their employers may be seen as the underlying purpose of all the regulatory provisions discussed in this paper.

Another basic right of critical importance in the employment context is the almost unique $^{28}$ right laid down by section 23(1) of the Constitution, which states that "[e]veryone has the right to fair labour practices". This very terse and yet extremely wide-ranging provision is the immediate source of the BCEA as well as Chapter VIII of the LRA, containing the protection of individual employees against unfair dismissal and unfair labour practices. ${ }^{29}$ The BCEA, in turn, is the source of South Africa's dedicated legislative instrument extending protection to domestic employees - Sectoral Determination 7: Domestic Worker Sector, South Africa of 2002 (hereafter "SD7"). ${ }^{30}$ This determination, supplemented by the other provisions referred to above, forms the substance of the discussion that follows.

\section{THE REGULATION OF DOMESTIC EMPLOYMENT IN SOUTH AFRICA}

undermine human dignity. In other words, the Constitution is concerned with the causes of inequality rather than the mere fact of bargaining inequality.

25 Act 66 of 1995.

${ }^{26}$ Act 55 of 1998.

27 Act 75 of 1997.

28 Only Malawi has a corresponding constitutional right, modelled on the South African precedent.

${ }^{29}$ See sections 2(a) of the BCEA and 1(a) of the LRA.

30 GNR.1068 of 15 August 2002. Sectoral determinations are issued by the Minister of Labour following an investigative procedure in terms of Chapter Eight of the BCEA in respect of sectors where no collective agreement negotiated at a statutory bargaining council is in force. In practice these are sectors where employees are unorganised or poorly organised, such as the domestic, farming and hospitality sectors. 
Over the past decade the number of domestic workers ${ }^{31}$ in South Africa has fluctuated at around one million, over $90 \%$ of whom are black women. ${ }^{32}$ According to government surveys the number decreased from 982000 in September 2002 - the month in which SD7 took effect - to a low of 971000 in September 2005, then recovered to 1019000 in September 2006 and 1003000 in September 2007.33 This casts doubt on the supposition that protective legislation would result in a significant decline in employment. The available evidence suggests that any such trend, if it existed at all, was limited both in its proportions and its duration. ${ }^{34}$

The significance of domestic employment in South Africa cannot be overestimated. In 2003 domestic workers in private households accounted for an estimated 8.7\% of all employees and $18.7 \%$ of women employees - in other words, almost one in five of all working women. ${ }^{35}$ For these women and many others - especially those who feel that they lack the skills to find employment in other sectors - domestic work may be the only opportunity of entering the job market. ${ }^{36}$ Many of them become the sole or main breadwinners of their families. Despite this, and despite the crucial role they play in enabling hundreds of thousands of others (in practice, especially women) to be employed in the formal economy, domestic work remains undervalued and domestic workers occupy a subordinate status in the labour market. In this sense the sector represents a touchstone of societal attitudes in South Africa. Reconceptualising domestic employment may be seen as part of a process of ideological transformation that is critical to South Africa's evolution into a whole society. At the same time the conditions experienced by domestic workers and their dependants, to the extent that they promote or retard a broader process of economic emancipation, have a direct impact on South Africa struggle for social transformation.

31 For the definition of "domestic worker", see fn 445 below.

32 In 1997 an estimated 89\% of domestic workers were African and 8.4\% were classified as Coloured: Claire Horton \& Mawethu Vilana Working Conditions of Domestic and Agricultural workers NALEDI Policy Memo (2001) 2. It must be emphasised, however, that the numbers are approximate

33 Statistics South Africa Labour Force Survey Statistical release P0210 (March 2009) Table 4.3. It must be emphasised, however, that the numbers are approximate and the numbers of domestic workers employed informally may not be accurately reflected.

34 Similarly, there is no clear evidence that the implementation of Sectoral Determination 8: Farm Worker Sector, South Africa (2 December 2002) resulted in job losses in the agricultural sector: see Mazibuko K. Jara Monitoring Compliance with the Sectoral Determination for Farm Workers in 5 Western Cape Farming Districts: Report of an Exploratory Study Women on Farms Project (2006) http://www.wfp.org.za/pdf/compliance to sectroral_determination_for_farm_workers_5_wes.pdf (accessed 26 June 2009) esp at 53-54. Employment levels, it is suggested, are determined by a multiplicity of factors in addition to wage levels. Sectoral Determination 8 has since been replaced by Sectoral Determination 13: Farm Worker Sector, South Africa (GNR.149 of 17 February 2006).

35 Statistics South Africa, Labour Force Survey Statistical release P0210 (March 2003) iii.

${ }^{36}$ Community Agency for Social Enquiry (CASE) Results of the survey on domestic workers and employers South African-German Development Co-operation Learnership Project (2001). 
2002 forms a convenient dividing line in considering the nature and effect of protective legislation in the domestic employment sector, given that this was when SD7 took effect. However, it needs to be seen in perspective. At least since 1994 domestic workers have enjoyed the protection of all the constitutional provisions referred to above. Since 1996 they have been protected against unfair dismissal and unfair labour practices as defined in the LRA. ${ }^{37}$ In 1998 obligatory minimum standards of employment were extended to all workers employed for 24 or more hours per month, including maximum working hours, entitlement to paid leave and numerous other rights. ${ }^{38}$ Despite this, the conditions of domestic workers remained precarious. Horton and Vilani, in a study carried out in 2001, identified the following problems amongst others:

- Domestic work tended to be undervalued and regarded as unskilled, resulting in very low wages;

- Hours of work tended to be long and irregular;

- Security of employment was very limited;

- Access to education and training was limited, resulting in the perpetuation of domestic workers' unskilled status;

- Domestic workers were exposed to personal abuse, including assault and sexual harassment. ${ }^{39}$

To the extent that these conditions were persisting, in other words, it meant that the existing legislation was ineffective in providing domestic workers with the intended protection. Indeed, in a study carried out for the ILO in 2000 the entire domestic sector was treated as part of the informal economy - in other words, beyond the reach of legal regulation..$^{40}$ Horton and Vilani sum up the reasons for this:

"While gains have been made in terms of legislation, such as the BCEA and Labour Relations Act, the intra-household nature of the relationship between domestic worker and employee, means that many employers do not implement the provisions of the legislation. Furthermore, many domestic workers are not aware of their rights and those that are aware fear reprisal from employers. Further, due

\footnotetext{
37 See in particular sections 185 to 195, LRA. The LRA initially included a prohibition of unfair discrimination, inter alia on the grounds of race, sex and gender, which, in 1999, was superseded by the more comprehensive protection contained in the EEA.

${ }^{38}$ See in particular Chapters Two to Five, BCEA. For background see Department of Labour Green Paper Policy Proposals for a New Employment Standards Statute (Government Gazette 17002, 13 February 1996).

${ }^{39}$ Horton \& Vilani (fn 3232 above) 2-3.

${ }^{40}$ ILO Women and Men in the Informal Economy (fn 9 above) 40, Table 3.4.
} 
to the dispersed nature of domestic work, monitoring of implementation is difficult." 41

For the same reasons, trade union organisation of domestic workers was limited. These conditions, which are characteristic of domestic employment internationally, encapsulate the argument in favour of the ILO's call for "[a] regulatory instrument that recognizes the specificity of domestic work and responds to the decent work deficit" in the form of a special Convention. ${ }^{42}$

The South African government certainly took the issue seriously. The process culminating in the proclamation of SD7 was launched in 1999. It involved 64 public hearings, 114 written representations, two surveys covering more than 300 employers and 4000 domestic workers, a study of the international context and an economic analysis. ${ }^{43}$ Despite the wide range of problems identified, however, SD7 was confined to minimum conditions of employment - in other words, the area covered by the BCEA. In some respects it did broaden the protection laid down by the Act with a view to addressing the specific circumstances of the domestic employment sector. For example:

- "domestic worker" is defined extensively to include independent contractors as well as workers employed or supplied by employment services; ${ }^{44}$

- provision is made for a domestic worker to be on "stand-by" between 20.00 and 06.00, subject to certain limitations, provided it is agreed in writing and a stipulated minimum allowance is paid; ${ }^{45}$

- domestic workers are entitled to five days instead of three days paid family responsibility leave; ${ }^{46}$ and

41 Op cit 2. Or, as the Minister of Labour said of the findings of an official investigation released at about the same time, it revealed "a picture of long hours, heavy workloads, high levels of control, regimented lifestyles, lack of privacy and high levels of job insecurity and powerlessness": South African Government Information Media Statement by the Honourable Minister of Labour, Mr Membathisi Mdladlana, on the Release of a Report about Wages and Conditions of Employment for Domestic Workers, 10 July 2001 at http://www.info.gov.za/speeches/2001/010710410p1001.htm (accessed 23 June 2009).

${ }^{42}$ ILO Report par 82; see also pars $327 \mathrm{ff}$.

${ }^{43}$ Media Statement by the Minister of Labour (fn 41 above).

${ }^{44}$ Clause 31. In section 1 of the BCEA "domestic worker" is defined as "an employee who performs domestic work in the home of his or her employer", including gardeners, persons "employed by a household as driver of a motor vehicle" and persons taking care of "children, the aged, the sick, the frail or the disabled, but does not include a farm worker" (emphasis added). Likewise, the protection provided by the LRA is confined to "employees", defined as excluding "independent contractors". Section 23(1) of the Constitution, on the other hand, extends the right to "fair labour practices" to "everyone". On the meaning of this distinction, see Halton Cheadle "Labour Relations" in Cheadle, Davis \& Haysom South African Constitutional Law: The Bill of Rights LexisNexis Butterworths (2002) par 18.2.1.

${ }^{45}$ Clause 14. 
- workers living in accommodation belonging to their employers are protected against summary eviction upon premature termination of the contract of employment. ${ }^{47}$

For the rest, SD7 largely follows or restates the provisions already contained in the BCEA. To judge its effect, its provisions, as supplemented by those of other statutes, may be compared with some of the key benchmarks suggested by the ILO Report.

\subsection{Remuneration}

Given the pervasiveness of low wages, the undervalued nature of domestic employment, the weakness of trade union organisation in the sector and the limited bargaining power of individual domestic workers, provision for minimum wages is crucial in promoting decent work. Of 66 ILO member states covered by the Report, almost two-thirds do set minimum wages for domestic workers. ${ }^{48}$ The Report further emphasises the importance of such wages being set at levels that will (i) contribute to poverty eradication, and (ii) recognise varying degrees of skill. ${ }^{49}$ SD7 meets the first of these criteria, in that minimum wages were initially set at above the prevailing median wage levels ${ }^{50}$ and must be increased annually by at least $8 \% .{ }^{51}$ It does not meet the second criterion in that wage differentials take account only of assumed cost-of-living differences between urban and rural areas and numbers of hours worked. ${ }^{52}$ Skills levels, however, are ignored. In respect of other problematic aspects of remuneration - for example, the provision of accommodation in part payment of wages - SD7 follows the ILO standards.

\subsection{Working time}

The ILO Report accepts that a 40-hour working week has become the international norm and stresses the importance of regulating night work as well as a minimum

\footnotetext{
46 Clause 21.

47 Clause 26.

48 Par 140, ILO Report.

${ }^{49}$ Pars $140-142$.

50 Making this "a significant intervention in the domestic worker labour market": Tom Hertz Have Minimum Wages Benefited South Africa's Domestic Service Workers? African Development and Poverty Reduction: The Macro-Micro Linkage: Forum Paper (2004) at http://www.wiego.org/occupational_groups/pdfs/South\%20Africa_Hertz_Minimum_Wages_for_D omestics.pdf (accessed 23 June 2009) 1.

51 Or more, if inflation exceeds $10 \%$ : see clause 3. Different rates are stipulated according to whether workers are employed for less or more than 27 hours per week: see clause 2 .

52 Clause 2 read with Table 1 . The distinction is between workers employed for more and less than 27 hours per week. The implication, apparently, is that all domestic workers are deemed to be equally skilled or unskilled.
} 
weekly rest period of at least 24 hours. $^{53}$ Of 71 countries surveyed, almost half imposed no limit on working hours of domestic workers and almost a third imposed limits in excess of 40 hours. ${ }^{54}$ South Africa is in the latter category: a limit of 45 ordinary hours per week applies to all employees, including domestic workers. ${ }^{55}$ Night work, however, is regulated (including the provision for "standby" mentioned above) and a weekly rest period of 36 hours is required. ${ }^{56}$

\subsection{Equality and non-discrimination}

Selection and recruitment, sexual harassment and testing for HIV/AIDS are some of the areas where, according to the ILO Report, discrimination against domestic workers is prevalent. ${ }^{57}$ While SD7 does not deal with discrimination, the EEA extends comprehensive protection to all employees against all forms of discrimination, including harassment, in line with ILO Convention 111 of 1958 on Discrimination (Employment and Occupation). ${ }^{58}$

\subsection{Termination of employment}

In terms of ILO Convention 158 of 1982 (Termination of Employment), the main criteria of fairness in dismissal are the requirements of "(i) valid reason for termination; (ii) pre-termination opportunity to respond; (iii) notice; and (iv) [right of] appeal to an independent body" ${ }^{59}$ Comprehensive protection encompassing all these requirements is provided by Chapter VIII of the LRA and, in practice, it is one of the forms of protection that domestic workers have most actively utilised. ${ }^{60}$ In relation to notice periods and "live-in workers", the

\footnotetext{
53 Pars 174 and 175.

${ }^{54}$ ILO Report, par 177.

55 Section 9 BCEA and clause 10, SD7. The BCEA also lays down a procedure for progressively reducing maximum working time to 40 hours per week: section 9(3) read with Schedule 1.

${ }^{56}$ SD7, clauses 13 and 16.

${ }^{57}$ ILO Report, pars 185-194. In some countries, indeed, domestic workers are excluded from protection against certain forms of discrimination. In Australia, for example, the Equal Opportunity Act, 1995 (Victoria) allows an employer to "discriminate in determining who should be offered employment for the provision of domestic or personal services in any person's home": par 185.

${ }^{58}$ See, in general, D. du Toit et al Labour Relations Law: A Comprehensive Guide $5^{\text {th }}$ ed (LexisNexis Butterworths 2006) Chapter 11.

${ }^{59}$ ILO Report, par 196.

${ }^{60}$ See Ian Macun, Daniel Lopes and Paul Benjamin An Analysis of Commission for Conciliation Mediation and Arbitration Awards DPRU Working Paper 08/134 (2008) at http://www.commerce.uct.ac.za/Research Units/DPRU/WorkingPapers/wp.asp?WP ID=2008/13 $\underline{4}$ (accessed 29 June 2009) Table 13 and 14. The main reason is probably that employees who have been dismissed no longer have to fear reprisals from the employer. The ILO Report, it may be
} 
provisions of SD7 are singled out in the ILO Report as illustrations of effective regulation. ${ }^{61}$

\subsection{Freedom of association}

The ILO Report identifies the organisation of domestic workers as a key aspect of "decent work in action" - i.e., the implementation of legislative protection - and notes that such organisation presupposes freedom of association and the right to bargain collectively. ${ }^{62}$ Yet, though both these rights are fundamental ILO principles, the Report adds that "in most parts of the world this category of workers [i.e., domestic workers] still lacks the legal protection to make them a reality".63

In South Africa the right of all workers to form and join trade unions, to engage in collective bargaining and to strike is protected by the Constitution and regulated by the LRA. ${ }^{64}$ In practice, however, these provisions (like much of labour law internationally) are modelled on the circumstances of "standard" employees working in formal workplaces and take little account of the circumstances of "nonstandard" employees, such as domestic workers, who work under very different conditions. ${ }^{65}$ This question will be returned to in the conclusion of this paper.

\subsection{Unemployment benefits}

Unemployment insurance is one of the forms of social protection addressed in the ILO Report and is also the subject of two Conventions. ${ }^{66}$ In 2003 South Africa

noted, erroneously includes South Africa among the countries where there is a "[r]ight to fire without providing a valid Reason": at 54 Table IV.3.

61 Pars 200 and 204, with particular reference to the requirement of four weeks' notice for domestic workers who have been employed for six months or more (clause 24) and regulation of eviction from accommodation in the case of "live-in workers" (clause 26).

${ }^{62}$ ILO Report, par 260.

${ }^{63}$ Ibid.

${ }^{64}$ Section 23, Constitution; chapters II, III and IV, LRA.

${ }^{65}$ Save to the extent that the isolation of domestic workers is increased by protection of their employers' right to privacy: trade unions' right of access to their members' workplaces 'does not include the right to enter the home of the employer, unless the employer agrees" (section 17, LRA), while labour inspectors may only enter a home that is also a workplace with (i) the consent of the owner or occupier or (ii) authorisation by the Labour Court: section 65(2) and (3), BCEA. On the more innovative regulation of inspection in Uruguay, see ILO Report par 251 Box VII.1.

66 That is, the Unemployment Convention 2 of 1919 and the Employment Promotion and Protection against Unemployment Convention 168 of 1988. The Unemployment Provision Convention 44 of 1934 , which permitted the exclusion of domestic workers, was shelved following the adoption of Convention 168. 
became one of only nine countries covered by the Report that explicitly extended unemployment benefits to domestic workers. ${ }^{67}$

\subsection{Drawing a balance}

SD7, in combination with other legislation, thus provides domestic workers with most of the core protections required by international standards. Because it confines itself to minimum conditions of employment, however, it does not address the more structural problems that are fundamental to the "decent work deficit" experienced by many domestic workers - in particular, the problems of disempowerment, lack of organisation, lack of compliance with labour standards and lack of effective enforcement arising from their isolation in private households. At the same time it may be argued that the achievement of decent work is a progressive process and that the setting of basic standards, even though initially observed only to a limited extent, is an essential first step in introducing a climate of compliance in an unregulated sector, placing workers in a stronger position and laying a basis for coming to grips with the more fundamental problems. We shall therefore look briefly at the impact of the existing regulation before considering, in conclusion, how it could be extended in order to address the underlying causes of the "decent work deficit".

\section{THE IMPACT OF REGULATION IN THE DOMESTIC EMPLOYMENT SECTOR}

Published research reflects two schools of thought which, at first sight, appear to contradict each other. On the one hand it is suggested that SD7 has had a significant impact and met with relatively positive levels of compliance. On the other hand it is argued that domestic workers generally remain exposed to appalling conditions, including servitude and forced labour.

An early statistical study covering the period September 2001 to September 2003 (i.e., the years preceding and following the implementation of SD7) painted a relatively positive picture. ${ }^{68}$ Despite widespread assumptions that SD7 would be ineffective, average nominal wages of domestic workers were found to have risen by $23 \%$ between September 2002 and September 2003 (compared with less than

${ }^{67}$ In terms of the new Unemployment Insurance Act 63 of 2001, as amended by the Unemployment Insurance Amendment Act 32 of 2003.

68 Hertz Have Minimum Wages Benefited South Africa's Domestic Service Workers? (fn 50 above). The data was drawn from the Labour Force Surveys conducted by Statistics South Africa in 2001, 2002 and 2003, covering some 30000 households each: ibid 2. The numbers of domestic workers included in the various surveys ranged from 3097 (February 2002) to 2430 (September 2003). 
$5 \%$ in the case of demographically similar groups of workers in other sectors). And, contrary to the belief that higher wages would translate into job losses, employment levels in the domestic sector did not decline significantly. ${ }^{69}$ In addition, following the introduction of SD7, the following changes were observed:

- the proportion of domestic workers registered for unemployment insurance and those with written contracts of employment ${ }^{70}$ rose from $3 \%$ and $7 \%$ respectively to $25 \%$;

- the proportion of workers earning less than the prevailing minimum wage fell from $75 \%$ to $61 \%$;

- the proportion of workers receiving paid leave increased from some $16 \%$ to some $21 \%$; and

- mean monthly earnings increased by $18,7 \%$ while mean hours worked per month decreased by $3,8 \% .^{71}$

An even more positive picture emerges from a survey of 68 employers of domestic workers carried out three years later in Emfuleni municipality in Gauteng Province. ${ }^{72}$ The study was concerned with the relationship between awareness of the legislation and compliance therewith, rather than with the impact of the legislation as such. However, while revealing limited awareness among employers of the requirements of SD7,73 it nevertheless suggested surprisingly high levels of actual compliance. For instance, while very few employers were aware of minimum wage levels, the wages reportedly paid by the vast majority were at or above those levels. ${ }^{74}$ Similarly, whereas few employers indicated awareness of maximum working hours and workers' entitlement to a meal break, the responses

69 That is, the decline of some 3\% in domestic workers as a proportion of the total working-age population was comparable to that recorded in respect of demographically similar groups of workers; no econometric evidence was found that the decline was causally connected to the wage increases: Hertz op cit 1. A more recent study adds that "during the last decade South African households have become smaller and more fragmented, and hence there are many more potential employers of domestic workers. Anecdotal evidence also suggests that more wealthy families now rely on two incomes, which has increased the demand for domestic services at homes. The impact of minimum wages may well have been countered by these effects": Development Policy Research Unit Minimum Wages, Employment and Household Poverty: Investigating the Impact of Sectoral Determinations (2008) 30.

${ }^{70}$ In fact, clause 9 of SD7 requires an employer to provide a domestic employee with specified particulars of employment in writing rather than to enter into a written contract.

${ }^{71}$ Hertz op cit passim.

72 Christel Marais “Labour legislation in Emfuleni's domestic worker sector: awareness and compliance” (2009) 33 South African Journal of Labour Relations 65. The respondents were all employees (academic and administrative) of a tertiary institution. In terms of racial classification, $69 \%$ of the employers were white, $24 \%$ African, $4 \%$ Indian and 3\% coloured.

73 The average "score" in terms of the questions asked to test such awareness was 46\%, ranging from a high of $92 \%$ (i.e., knowing almost everything about SD7) to a low of $0 \%$ (i.e., knowing nothing about it).

${ }^{74}$ I.e., $83 \%$ and $89 \%$ in respect of workers employed for more and less than 27 hours per week respectively. 
of $100 \%$ and $99 \%$ respectively indicated actual compliance. The lowest levels of compliance were in respect of what might be termed administrative requirements - for example, recording the terms of the employment contract in writing (59\%), issuing a detailed payslip (31\%), giving written notice of termination (22\%) and issuing a written certificate of employment upon termination (11\%).

It is also interesting to note the factors seen by employers as standing in the way of compliance with the legislation. The most significant, in order of importance, were "no time to study requirements of law", "not fully aware of the requirements of the law" and "compliance will just complicate our relationship". Very few (only 3.51\% of employers who considered themselves compliant) stated that they disagreed with the legislation.

The discrepancy in levels of compliance revealed by the above two studies may be explained in the first place by the difference in sample sizes. The small size of the 2006 sample means that no general conclusions can be drawn from it. In addition, it is possible that the occupationally uniform and atypical nature of the respondents may have further skewed the results.

A very different impression is created by an article by Woolman and Bishop, where it is argued that "quite a significant amount of farm labour and domestic labour can be characterised as [servitude]". ${ }^{75}$ Servitude, it is pointed out, is prohibited by section 13 of the Constitution. With reference to international law, the authors put forward the following "broad definition":

"Servitude is about caste or status. Persons in conditions of servitude occupy a social station that does not allow them to alter the conditions of their existence: their station makes it appear that they work 'voluntarily' for those above them. Servitude appears voluntary because this form of dominion of man over man is underwritten by 'law, custom or agreement' and not by a particular legal relationship of control of one person over another. Such 'law, custom or agreement' refers to social understandings and not to any consent by the bondsman to abject conditions." 76

Most of the empirical evidence relied on to identify conditions of servitude, however, relates to farm workers rather than domestic workers. While stating that the condition of domestic workers "bears more than a passing resemblance to that of farm workers", the actual data cited in support of this contention relate to fluctuations in earnings among unskilled workers in general rather than the conditions of domestic workers in particular. It is noted that unskilled earnings declined between 1995 and 2002, then increased by 27\% between 2002 and 2005,

\footnotetext{
75 Stu Woolman and Michael Bishop "Down on the farm and barefoot in the kitchen: farm labour and domestic labour as forms of servitude" Development Southern Africa vol. 24, no. 4, pp. 595-606 at http://www.up.ac.za/dspace/handle/2263/4268\#files (accessed 26 June 2009) 1.

76 Ibid 3.
} 
but that by 2005 "average female earnings were still slightly below the 1995 level". Apparently on the strength of this it is concluded that "[o]ver the past decade real wages for female domestic workers have fallen."77 The only illustration of servitude that is discussed is a United States criminal matter in 1947 where the definition of "servitude" was extended to include the condition of a domestic worker performing de facto compulsory labour.

It may be concluded that authors' application of the concept of servitude is somewhat broad 78 and that such conditions affecting domestic workers are assumed rather than demonstrated. More pertinent for present purposes, however, is the authors' comment on Hertz's findings (above). While not questioning the improvements identified by Hertz, it is noted that "such news is not really 'all that cheery'. Only 25 per cent of workers have a written contract and have UIF deducted. Only 22 per cent receive paid leave." 79 The point is clear: $75 \%$ of workers did not have a written contract; $78 \%$ did not receive paid leave. In 2003, at very least, the transformation that SD7 was intended to set in motion still had a long way to go.

A more recent study presents evidence of a far more concrete and disturbing nature, not only of poor working conditions but of actual servitude and forced labour. ${ }^{80}$ The study deals with internal trafficking ${ }^{81}$ in persons (mainly teenage girls and young women) for various purposes, of which prostitution is the most prevalent and domestic employment the second most prevalent, though in some cases the latter serves as a conduit into the former. Interviews with 41 participants with direct or indirect knowledge of trafficking for the purpose of domestic servitude revealed a grim picture of "organized employment agencies that actively recruited female work seekers, particularly coloured girls and young women from the Central Karoo in Western Cape as well as the Northern, North

\footnotetext{
77 Ibid 6, 7.

78 Thus, civil imprisonment of debtors for contempt of court (struck down as unconstitutional in Coetzee v Government of the Republic of South Africa (1995) (4) SA 631 (CC)) is cited as "as a species of servitude" in that "[t]he debtor was obliged to stay in prison because of his status - his inability to pay off a debt" (ibid 3). The consequences of failure to comply with a legal requirement, in other words, are seen as arising from the "status" of the person concerned rather than her or his conduct. 79 Ibid 8.

80 Laura Gauer Bermudez "No Experience Necessary": The Internal Trafficking of Persons in South Africa International Organization for Migration (IOM), Regional Office for Southern Africa (2008) at http://iom.org.za/site/index.php?option=com docman\&task=cat view\&gid=21\&Itemid=50 (accessed 26 June 2009). The study is based on interviews with 208 persons, 108 of whom had direct knowledge of trafficking, 39 of whom had indirect knowledge and 16 of whom were victims of trafficking: ibid 25, 29.

81 Defined as "South African nationals [being] recruited under false pretence or through the use of force and transported from one location to another within South Africa for the purpose of exploitation": ibid 24. "Exploitation" is defined as including "forced prostitution, domestic servitude, forced labour within the agricultural sector, forced begging, or the forced/ involuntary removal of organs for the purposes of traditional medicine": ibid.
} 
West, and Eastern Cape Provinces, and transported to the suburbs surrounding Cape Town". ${ }^{82}$

Young coloured women are the favourite targets, usually driven into the hands of recruiters by rural destitution and the lack of job prospects. Transport and "accommodation" costs as well as a "placement fee" of R250 to R400 paid by the employer are charged against the victim's salary, thus effectively placing her in a position of debt bondage. ${ }^{83}$ Harrowing examples are given of the abuse to which victims are then exposed. The role of the Department of Labour in this process is called into question. "Despite the fact that recruitment agencies that operate largescale trafficking operations for this purpose are registered with the Department to Labour," the report states, "little to no monitoring or punitive measures were cited for those who break labour laws." 84 Labour inspectors, for their part, cite the prohibition on entering domestic premises without the home-owner's consent as a major obstacle to monitoring the conditions of domestic workers. ${ }^{85}$

Against this background the positive impact of SD7 can only be described as limited and uneven. The fact that traffickers in domestic workers appear to find their clients in relatively affluent suburbs casts doubt on the (perhaps naïve) hypothesis that compliance with minimum conditions of employment is determined primarily by employers' ability to afford it. At the same time, episodic evidence suggests the existence of a significant informal domestic employment sector in black townships where conditions fall far short of the requirements of SD7. ${ }^{86}$ All in all, it may be inferred that factors as intangible as the socio-political awareness and attitudes of employers are no less important than their economic status, or levels of enforcement, in determining compliance with the law.

\section{CONCLUSIONS}

\footnotetext{
82 Ibid 46.

83 Ibid 47. Clients are "most frequently noted to be of the Muslim faith and of South Asian descent", typically residing in "middle class" suburbs: ibid 47, 48.

84 Ibid 45. The reference to registration with the Department of Labour is unclear. The only requirement of this nature relates to persons wishing "to provide employment services for gain" for purposes of the Skills Development Act 97 of 1998. The duty of labour brokers to register in terms of the Labour Relations Act 28 of 1956 was abolished by the present LRA.

85 Interview with officials of the Department of Labour inspectorate, Cape Town, 20 March 2009. The vast majority of complaints from domestic workers, it was added, relate to non-payment or underpayment of minimum wages; and many complaints are lodged by domestic workers on behalf of others - in other words, the actual complainants prefer not to communicate personally with the Department. The officials were strongly of the view that the legislation and/or SD7 should be amended to take account of these and other problems.

86 Cf Magwaza op cit (fn 10 above).
} 
It is a truism that effective regulation of socio-economic activity depends on compliance by participants (whether through internalisation of the applicable norms and values or through pressure exercised by other parties, as in the relationship between employers and organised labour) as much as on enforcement by the state. This is manifestly the case in the domestic employment sector. More effective regulation in this and in other poorly regulated sectors, it is submitted, will be achieved not so much by means of intensified enforcement as by creating conditions in which greater compliance by employers will be encouraged. ${ }^{87}$

It is equally true that no social problem can be resolved unless it is addressed holistically - in other words, dealing with its causes as well as its manifestations. Disregard of legal requirements in the domestic employment sector feeds on a "supply side" of vulnerable people driven to submit to exploitation by poverty and unemployment. Any serious effort to eradicate such exploitation - in this as in other sectors - must ultimately be understood as part of the broader programme of social transformation mandated by the Constitution, ${ }^{88}$ including poverty alleviation, relevant education and training, and the extension of social services. Indeed, this has been acknowledged and has formed part of government vision at least since $1994 .{ }^{89}$ The question is the manner in which this vision is to be implemented and, specifically, how the regulation of domestic employment is to be integrated with other aspects of policy on which it is contingent.

Within this framework, the following are some of the hypotheses remaining to be tested:

- Employer indifference or resistance (active or passive) remains the single greatest barrier to more effective regulation in a sector such as this. To break through this barrier, the background and causes of non-compliance need to be better understood. The promulgation of SD7, it has been noted, was preceded by an extensive consultative exercise. Arguably, the exercise did not go far enough; by its nature it tended to focus more on the parties' immediate expectations in terms of employment conditions than on underlying determining factors. Amendments to SD7 and other applicable legislation, it is suggested, could be rendered more effective by broadening the scope of the preceding inquiry and revisiting the institutional framework within which it takes place. In addition to inviting submissions from interested parties in

${ }^{87}$ For example, tax incentives. Thus, in Brazil, employers can claim "income tax deductions linked to the payment of social security benefits on behalf of the domestic worker to the National Institute of Social Security (INS)": ILO Report par 147.

88 On this question, see the seminal article by Karl Klare: "Legal Culture and Transformative Constitutionalism" (1998) 14 SA Journal on Human Rights 146.

${ }^{89}$ See, for example, the Reconstruction and Development Programme, 1994 (policy framework of South Africa's first Government of National Unity, 1994-1996) at

http://www.anc.org.za/rdp/index.html and its successor, the Accelerated and Shared Growth Initiative for South Africa (AsgiSA) Annual Report 2006 at

http://www.info.gov.za/view/DownloadFileAction?id=72516 (accessed 27 June 2009). 
terms of Chapter Eight of the BCEA, there is a case for a more inclusive process aimed at engaging not only trade unions and interest groups representing employers but all role-players, including experts from specialist NGOs and academia. From such in-depth debate and negotiations based on detailed research it is possible that new structures for formulating legislation, more sensitively attuned to the various interests involved and more likely to find acceptance among all parties, could emerge. ${ }^{90}$

- The low esteem in which the work performed by domestic workers is held presents a formidable barrier to reducing the power imbalance between workers and employers. It is important in this context to guard against approaches which, though well-meant, may be paternalistic and ultimately disempowering. ${ }^{91}$ Rather, the work performed by domestic workers needs to be revalued and professionalised as a step towards dismantling this barrier. Various initiatives have been taken towards this end, including a government proposal for a "Strategic Skills Development Plan (a training and career development plan) for domestic workers" and a three-year Domestic Workers' Skills Development Project implemented between 2002 and 2005.92 It is necessary to study the outcomes of these initiatives more closely, as well as the obstacles which they encountered, in order to build further towards the objective of a qualifications framework for domestic workers linked to wage determination. More highly trained and confident domestic workers will be better able to command the respect of employers and stand up for their rights.

- Lack of organisation among domestic workers severely undermines the implementation of minimum conditions of employment and monitoring thereof. For all the reasons explained by Kahn-Freund, ${ }^{93}$ legal reform in the absence of organisation is unlikely to be any more effective in the future than it has been for the past 15 years. At the same time the dispersed and isolated

\footnotetext{
90 An interesting precedent has been set by the tripartite wage board recently established in Uruguay to negotiate terms and conditions of employment in the domestic employment sector: see ILO Report par 146.

${ }^{91}$ For example, the finding of the British Columbia Court of Appeal that an employer is bound by a "fiduciary relationship" with a domestic worker in addition to a contractual relationship, unlike in the case of other employees: Mustaji v. Tjin (1996), 30 C.C.L.T. (2d) 53, discussed in ILO Report par 254.

92 Department of Labour Design of new training plan for domestic workers at http://www.info.gov.za/speeches/2000/000824410p1003.htm (accessed 30 June 2009). For an analysis of the Domestic Workers' Skills Development Project and its positive outcomes, see Tersia Susara Wessels The Development Impact of the Domestic Workers Skills Development Project on its Participants (MA thesis, University of South Africa, December 2006) at http://uir.unisa.ac.za/handle/10500/1720 (accessed 14 April 2010). See also Terry Bell "Domestics want cash-flush state to revive skills plan" Business Report 27 October 2006 at http://www.busrep.co.za/index.php?fSectionId=559\&fArticleId=3507110 (accessed 30 June 2009) ${ }^{93}$ See 5-6 above.
} 
nature of domestic employment means that the organisation of domestic workers by traditional trade union methods will remain extremely difficult. To make inroads in sectors such as this, trade unions will be compelled to broaden their horizons beyond the traditional activities of collective bargaining and employee representation, ${ }^{94}$ for which there is little scope in the sector as presently constituted. The range of personal and social pressures experienced by domestic workers may challenge any trade union seeking to build widespread support among them to take the form of a "social movement union"95 representing its members' interests on a variety of fronts other than (though ultimately bearing on) conditions of employment - for example, gaining better access to education and training, decent housing, social benefits, etc. This should be seen as an important field of research as well as learning. In addition to the experience gained in South Africa over the past two decades of organising under difficult conditions, trade unions and other forms of organisation among domestic workers internationally offer various examples of meeting the challenges of the sector in new ways. ${ }^{96}$

It should be reiterated that, even though the law can only play a limited role in these processes, that role remains important and, possibly, even more important in a country such as South Africa where government is under a constitutional obligation to give effect to domestic workers' fundamental rights. Government is in a stronger position than any other actor to marshal the various instruments of labour market regulation towards this end. Woolman's conclusion in this regard is apposite:

"[M]any domestic workers and farm labourers toil in conditions of servitude in South Africa and ... a FC 13 challenge ${ }^{97}$ might just put the government on notice that it needs to create a comprehensive and coordinated programme to restore the dignity of these individuals." 98

It remains to be seen whether such a challenge will prove necessary or whether government will be persuaded of its own accord to build with all due urgency on

\footnotetext{
${ }^{94}$ Including the development of new and innovative methods of organisation; in recruiting members, for example, SADSAWU has targeted malls where domestic workers go shopping rather than the traditional method of seeking them out in the (inaccessible) workplace.

95 The term is borrowed from Sikhula Sonke, described as a "social movement trade union" of farm workers. Launched in 2004, it had by 2009 attracted some 3500 members mainly in five districts of the Western Cape. While there are important differences between the farming and domestic sectors, it is submitted that unions in the two sectors have much to learn from each others' experiences. In general, see Mazibuko K. Jara Monitoring Compliance with the Sectoral Determination for Farm Workers (fn 34 above).

${ }^{96}$ See ILO Report, chapter VIII. See also Women in Informal Employment: Globalizing and Organizing (WIEGO) Informal workers in focus: Domestic workers (2008) at http://www.wiego.org/publications/FactSheets/WIEGO Domestic Workers.pdf (accessed 26 June 2009).

${ }^{97}$ I.e., based on section 13 of the Constitution, requiring government to enforce the prohibition of servitude and forced labour.

98 Woolman and Bishop op cit (fn 75 above) 9.
} 
the initiatives that have already been taken to transform the domestic employment sector into a paradigm of decent work. 


\section{BIBLIOGRAPHY}

\section{Books and chapters in books}

Martin Brassey and Carole Cooper "Labour Relations" in Chaskalson et al Constitutional Law of South Africa (Juta 1996)

Halton Cheadle "Labour Relations" in Cheadle et al South African Constitutional Law: The Bill of Rights (LexisNexis 2002, looseleaf)

Jacklyn Cock Maids \& Madams: A Study in the Politics of Exploitation (Ravan Press 1980), republished as Maids and Madams: Domestic Workers under Apartheid (The Women's Press, 1989).

Paul Davies and Mark Freedland Kahn-Freund's Labour and the Law $3^{\text {rd }}$ ed (Stevens 1983)

D. du Toit et al Labour Relations Law: A Comprehensive Guide $5^{\text {th }}$ ed (LexisNexis Butterworths 2006)

Francis B Nyamnjoh Insiders and Outsiders: Citizenship and Xenophobia in Contemporary Southern Africa (Zed Books, 2006)

Alan Rycroft and Barney Jordaan A Guide to South African Labour Law 2 ed (Juta 1992)

\section{Articles, papers and reports}

Paul Benjamin Labour Market Regulation: International and South African Perspectives (Employment \& Economic Policy Research Programme, Human Sciences Research Council, October 2005)

Paul Benjamin “Beyond 'lean' social democracy: labour law and the challenge of social protection" (2006) 60 Transformation 32

Laura Gauer Bermudez "No Experience Necessary": The Internal Trafficking of Persons in South Africa International Organization for Migration (IOM), Regional Office for Southern Africa (2008) at http://iom.org.za/site/index.php?option=com docman\&task=cat view\&gid=21\&It emid $=50$ (accessed 26 June 2009)

Community Agency for Social Enquiry (CASE) Results of the survey on domestic workers and employers (commissioned by the Department of Labour and German Technical Co-operation, May 2001) at http://www.case.org.za/index.php?option=com content\&view=article\&id=35:res ults-of-a-survey-on-domestic-workers-andemployers\&catid $=4:$ articles\&Itemid $=14$

Tom Hertz Have Minimum Wages Benefited South Africa's Domestic Service Workers? African Development and Poverty Reduction: The Macro-Micro Linkage: 
Forum Paper (2004) at

http://www.wiego.org/occupational groups/pdfs/South\%20Africa Hertz Minimu m Wages for Domestics.pdf (accessed 23 June 2009)

Claire Horton \& Mawethu Vilana Working Conditions of Domestic and Agricultural workers NALEDI Policy Memo (2001)

International Labour Organisation Women and Men in the Informal Economy: A

Statistical Picture Geneva 2002

http://www.wiego.org/publications/women\%20and\%20men\%20in\%20the\%20i nformal \%20economy.pdf (accessed 19 June 2009)

International Labour Office Decent work for domestic workers Report IV(1), International Labour Conference, 99 $9^{\text {th }}$ Session, 2010: Geneva, First edition 2010 at http://www.ilo.org/wcmsp5/groups/public/---ed norm/---

relconf/documents/meetingdocument/wcms 104700.pdf (accessed 20 June 2009)

International Trade Union Confederation "Spotlight interview with Barbro Budin (IUF - Equality Officer)" at http://www.ituc-csi.org/spip.php?article1895

(accessed 19 June 2009)

International Trade Union Confederation "Spotlight interview with Esther Stevens (SADSAWU - South Africa)" at http://www.ituc-

csi.org/spip.php?article1483\&lang=en (accessed 20 June 2009)

International Trade Union Confederation: Statement dated 13 February 2008 at http://www.ituc-csi.org/spip.php?article1811 (accessed 20 June 2009)

Mazibuko K. Jara Monitoring Compliance with the Sectoral Determination for Farm Workers in 5 Western Cape Farming Districts: Report of an Exploratory Study Women on Farms Project (2006) at

http://www.wfp.org.za/pdf/compliance to sectroral determination for farm wor kers 5 wes.pdf (accessed 26 June 2009)

Ian Macun, Daniel Lopes and Paul Benjamin An Analysis of Commission for Conciliation Mediation and Arbitration Awards Development Policy Research Unit Working Paper 08/134 (2008) at http://www.commerce.uct.ac.za/Research Units/DPRU/WorkingPapers/wp.asp? WP ID=2008/134 (accessed 29 June 2009)

Thenjiwe Magwaza "Effects of Domestic Workers Act in South Africa: A steep road to recognition" Agenda No 78 (2008)

Christel Marais “Labour legislation in Emfuleni's domestic worker sector: awareness and compliance" (2009) 33 South African Journal of Labour Relations 65

Women in Informal Employment: Globalizing and Organizing (WIEGO) Informal workers in focus: Domestic workers (2008) at 
http://www.wiego.org/publications/FactSheets/WIEGO Domestic Workers.pdf (accessed 26 June 2009)

Tersia Susara Wessels The Development Impact of the Domestic Workers Skills Development Project on its Participants (MA thesis, University of South Africa, December 2006) at http://uir.unisa.ac.za/handle/10500/1720 (accessed 14 April 2010)

Stu Woolman and Michael Bishop "Down on the farm and barefoot in the kitchen: farm labour and domestic labour as forms of servitude" (2007) 24 Development Southern Africa 595 available at http://www.up.ac.za/dspace/handle/2263/4268\#files (accessed 26 June 2009)

\section{Website}

International Domestic Workers Network "Respect and Rights for Domestic Workers" at http://www.domesticworkerrights.org/

\section{Official publications}

Accelerated and Shared Growth Initiative for South Africa (AsgiSA) Annual Report 2006 at http://www.info.gov.za/view/DownloadFileAction?id=72516 (accessed 27 June 2009)

Department of Labour Green Paper: Policy Proposals for a New Employment Standards Statute (Government Gazette 17002, 13 February 1996)

Department of Labour Design of new training plan for domestic workers at http://www.info.gov.za/speeches/2000/000824410p1003.htm (accessed 30 June 2009)

Reconstruction and Development Programme, 1994 (policy framework of South Africa's first Government of National Unity, 1994-1996) at http://www.anc.org.za/rdp/index.html (accessed 27 June 2009)

Statistics South Africa Labour Force Survey Statistical release P0210 (March 2009)

South African Government Information Media Statement by the Honourable Minister of Labour, Mr Membathisi Mdladlana, on the Release of a Report about Wages and Conditions of Employment for Domestic Workers, 10 July 2001 at http://www.info.gov.za/speeches/2001/010710410p1001.htm (accessed 23 June 2009)

\section{Legislation}

(South African)

Basic Conditions of Employment Act 75 of 1997 
Labour Relations Act 66 of 1995

Sectoral Determination 7: GNR.1068 of 15 August 2002

Unemployment Insurance Act 63 of 2001

(ILO Conventions)

Unemployment Convention 2 of 1919

Employment Promotion and Protection against Unemployment Convention 168 of 1988

\section{Case law}

Coetzee v Government of the Republic of South Africa (1995) (4) SA 631 (CC) 